\title{
Off-grid opportunities and threats in the wake of India's electrification push
}

\author{
Anthony P. Heynen ${ }^{1 *}$ (D), Paul A. Lant ${ }^{1}$, Simon Smart ${ }^{2}$, Srinivas Sridharan ${ }^{3}$ and Chris Greig ${ }^{2}$
}

\begin{abstract}
Background: In pursuing the United Nations' Sustainable Development Goal of affordable, reliable, sustainable and modern energy access for all, India's electrification efforts are dominated by a central electricity grid, with 100\% of villages now connected. Despite this, 305 million people still remain without electricity. Off-grid electrification may play an important role in energy access for these 'last mile' consumers. However, opportunities are directly influenced by government plans and policies, including the integration of grid and off-grid systems. This paper aims to provide a contemporary assessment of the policies of the government, and how they manifest in electrification systems in rural and remote India, revealing opportunities and threats for the sector.

Method: The progress of village electrification is examined via policy announcements and the Indian government's dedicated websites on progress. The role and extent of off-grid systems are then examined in two contrasting Indian states: industrialised Maharashtra and less-developed Odisha. Publically-available information is supplemented with data obtained directly from known private sector operators and state agencies. The geographic and societal setting of off-grid locations is then examined to provide contextual commentary. Finally, interviews with key stakeholders (regulatory authorities, distribution companies, private firms, industry bodies and academia) were undertaken to validate findings.

Results: There is evidence of some remote localities not included in the government's electrification programs. The grid's poor quality and reliability, along with affordability barriers, means that the government's grid connection efforts may not result in significant improvements in electricity use by some consumers. Data from Maharashtra and Odisha showed limited private sector off-grid systems, generally operating on the periphery of government programs. This is despite the fact that there seems to be an opportunity for the private sector to enter the market, given the grid's shortcomings.

Conclusion: The shortcomings of India's centralised electrification paradigm could be overcome through more localised off-grid solutions that can access 'last mile' consumers. The government might consider achieving this by formally recognising the role of off-grid systems in India's electrification objectives. Further, the government could extend the reach of electrification by transferring responsibilities for household electricity access to local-level businesses and community organisations.
\end{abstract}

Keywords: Electricity access, Rural electrification, Off-grid, India

\section{Background}

India recently celebrated a significant milestone in its efforts to modernise: on 28 April 2018, the Prime Minister announced that the government had electrified $100 \%$ of villages in the country [1]. This achievement, towards meeting the United Nations' Sustainable Development Goal of affordable and clean energy access for all, is diluted

\footnotetext{
*Correspondence: a.heynen@uq.edu.au

${ }^{1}$ Energy \& Poverty Research Group, School of Chemical Engineering, The

University of Queensland, Brisbane, Australia

Full list of author information is available at the end of the article
}

by a more sobering reality: 305 million people in India are still without access to electricity [2] with many millions more experiencing unreliable supply [3]. The explanations for this discrepancy lie fundamentally in definitions of both 'village' and 'electrification' and that village and household connections do not equate to access and use [4]. Despite the grid's geographic reach to India's villages, localities at a sub-village level may miss out. Low supply reliability, with some areas receiving power for only a few hours a day [5], also means that increased connections to the grid may not

(c) The Author(s). 2019 Open Access This article is distributed under the terms of the Creative Commons Attribution 4.0 International License (http://creativecommons.org/licenses/by/4.0/), which permits unrestricted use, distribution, and reproduction in any medium, provided you give appropriate credit to the original author(s) and the source, provide a link to the Creative Commons license, and indicate if changes were made. 
directly translate to increased electricity use within households.

Off-grid electrification, where electricity for household or productive uses is generated without a connection to the grid, is acknowledged by the government and scholars $[5,6]$ as playing an important and complementary role in achieving electrification targets. However, despite the benefits of off-grid systems over the grid in a number of settings [7], the government generally remains committed to the grid paradigm for most situations, ostensibly for political reasons [8]. Opportunities for the private sector, including Non-Government Organisations (NGOs), to provide off-grid solutions outside of Indian government programs, are worthy of consideration. Some literature suggests that a potential market awaits private sector investment in the provision of off-grid systems by directly engaging with rural and remote communities and consumers $[6,9,10]$. However, such opportunities are directly influenced by government policies related to the foreseeable roll-out and integration of government grid and off-grid systems. Thus, understanding the policies of the government, and how they manifest in electrification systems in rural and remote India, is critical.

Energy access policies in India stem from the Electricity Act 2003, where both state and central governments are jointly tasked with providing electricity access to all areas of the country, including villages and hamlets [11]. The Rural Electrification Policy of 2006 [12] further embeds the electricity grid as the preferred and dominant mode of delivering electricity to cities, towns, villages and industries in India. The co-governance approach of the Electricity Act has arguably led to a somewhat fragmented and bureaucratic implementation [6], but steady progress has ensured that the grid now reaches all villages in India [13]. The primary political initiative to achieve electrification since 2005 was the Rajiv Gandhi Grameen Vidyutikaran Yojana (RGGVY). This was relaunched in August 2015 as the Deen Dayal Upadhyaya Gram Jyoti Yojana (DDUGJY)-a wider-ranging electrification plan incorporating both grid and off-grid solutions [14]. At its launch, Indian Prime Minister Narendra Modi declared that all 18,452 villages identified as unelectrified would be electrified in 1000 days [13]. The villages were identified via the 2011 Census using the term 'revenue village' [15]-locations that have clearly demarcated geographic boundaries and may encompass isolated hamlets not connected to the main population centre. The majority of these unelectrified villages were located in remote or inaccessible areas, or in areas affected by the activities of left-wing insurgents. ${ }^{1}$

The Rural Electrification Policy 2006 defines the conditions under which a village is deemed to be electrified: distribution lines need to be provided in the inhabited locality as well as in a minimum of one Dalit Basti (hamlet); public places, such as schools and community centres, need to be electrified; and at least $10 \%$ of all households in the village are required to be electrified. There are strong political drivers for the Indian government's preference for grid electricity as a national development tool. Some communities may aspire to a centralised grid supply as it is perceived as modern [5]; moreover, grid electricity represents a higher aspirational promise from political parties to rural voters [17] and may also form an important component of counter-insurgency efforts. The progress of DDUGJY village electrification is publically reported online [13], although there is anecdotal evidence that discrepancies exist between the government's official counts of electrified villages and reality [18].

Most recently, reporting on household connectivity has been targeted through the Saubhagya scheme (more formally, the Pradhan Mantri Sahaj Bijli Har Ghar Yojana) launched in late September 2017 [19], with the aim of achieving universal household electrification by December 2018. To facilitate this, the government committed to provide free grid connections to Below Poverty Line (BPL) households (identified using Socio-Economic and Caste Census (SECC) data, which also includes female-headed household criteria) [19]. Those households not meeting BPL criteria are able to connect to the grid for a fee (₹500-approximately US\$7), which can be spread over ten instalments [19]. The scheme is focussed on connections and does not include any additional subsidies for electricity usage, which is in the domain of state distribution companies. The Saubhagya scheme is ambitious, targeting 25 million rural households and five million urban households which are unelectrified and not covered under broader DDUGJY initiatives, as at October 2017 [19].

Recent studies have analysed the evolution of the rural electrification process in India [20]; evaluated the role of off-grid systems in national rural electrification plans in a number of countries [5, 21]; modelled the broad relationship between grid and off-grid electrification in India [6]; and examined the role and motivation of selected firms operating in the Indian off-grid sector [22]. This paper contributes to this ongoing dialogue by uniquely offering a detailed assessment of the contemporary situation in India. Specifically, the purpose of this paper is to examine the policy and extent of off-grid distribution in the context of India's current electrification progress, and the resultant opportunities and threats. Firstly, the paper determines the role and extent of grid and off-grid systems more broadly, and private sector off-grid systems specifically, in providing electricity to unelectrified villages and households. A situational analysis of off-grid systems in two states with vastly different energy development stories, Maharashtra and Odisha, shows that the government dominates the sector, with limited private 
sector systems documented. The potential role of private sector off-grid systems in the energy mix in India is investigated, with a particular emphasis on opportunities and threats. Localities not recorded on the Census may be the most pertinent market for private sector systems, although opportunities also arise from the poor reliability of the grid. The paper concludes with a discussion of the future role and integration of grid and off-grid systems in India and recommendations on how policy can support this.

\section{Methodology}

The progress of village electrification was examined via publically-reported online information and the Indian government's dedicated websites on village and household electrification progress [13, 23]. Data on progress was cross-checked against policy announcements and contextual information available in various literature. After establishing the extent of grid systems, the methodology turns to an analysis of the role and extent of off-grid systems in two contrasting Indian states: Maharashtra, containing large, developed urban conglomerations centred on Mumbai and India's main industrial centres, and Odisha, at the opposite end of the socio-economic spectrum with much lower levels of development, population and industrial activity [24]. Data was obtained from Prayas (Energy Group)'s Distributed Renewable Energy (DRE) map [25], which provides one of the only comprehensive compilations of the sector's operations. In acknowledging that this data source was not current, additional data was obtained directly from known private sector operators. The analysis also incorporated information on off-grid operations from state nodal agencies, Maharashtra Energy Development Agency (MEDA) and Odisha Renewable Energy Development Agency (OREDA). Whilst these sources did not comprehensively account for every off-grid operation in Maharashtra and Odisha, in the absence of a central registry, they do provide an invaluable data set. The geographic setting of the off-grid locations was examined using Google Maps, allowing some commentary to be made on remoteness and environmental factors. Using the Indian Census database [15], locations were checked to determine their official status, which would in turn indicate that they were part of the government's electrification program.

Interviews with key institutional stakeholders were undertaken in March 2017 to validate and verify the results obtained from document data and literature reviews. Government perspectives were obtained from representatives of MEDA; OREDA; the Odisha Electricity Regulatory Commission (OERC); Odisha's grid transmission company, GRIDCO; and the Indian government's Ministry of New and Renewable Energy (MNRE). Other interviews were conducted with representatives of Prayas (Energy Group); Odisha-based NGO Yuva Vikas; consultancy firm Customised Energy Solutions; and the industry body Clean
Energy Action Network (CLEAN). Finally, three perspectives were obtained from academics at the Indian Institute of Technology (IIT) Bombay; Xavier Institute of Management Bhubaneswar (XIMB); and The Energy and Resources Institute (TERI), Delhi.

\section{Results and discussion}

\section{Grid electrification}

Whilst significant progress has undoubtedly been made, the metrics of the Indian government continue to focus on infrastructure connections rather than electricity use. These definitions, with low thresholds of connectivity, mean that reported progress on village electrification does not provide a reliable indication of actual electricity use and the enhancement of capabilities that it provides [4]. Since April 2018, all 18,452 villages identified in August 2015 have been electrified, but only $8 \%$ have $100 \%$ of households connected [13]. A distributed transformer in a village and transmission lines to individual households does not necessarily indicate the availability of reliable, affordable electricity and its use by consumers. A recent report from the Council on Clean Energy, Environment and Water (CEEW) [26] showed the significant improvements in energy access across five states between 2015 and 2018 but did highlight the often very real disconnect between electricity connections and energy poverty alleviation, due to implementation, quality/ reliability and affordability issues.

Household electricity use may be best ascertained by direct surveys of household lighting, which are most comprehensively undertaken in the Census held every 10 years. Percentage of the population electrified can be estimated based on new households connected but must also take into account changes in demographics, such as population increases and shifts from rural to urban settings. Access-to-electricity data from the World Bank for the period 1995-2014 (Fig. 1), based on Indian government data, shows two dips in an otherwise steady rise in access. These dips occur in 2001 and 2011, India's most recent Census years. This has led to speculation [27] that, for most years, there is an apparent over-estimation of the percentage of the population electrified, interrupted only by the more-reliable data garnered from Census surveys on lighting use.

The extent of actual electrification may also be constrained by definitions of a village. Some hamlets and caste settlements may be categorised via the Census as being part of a village, when in reality, they are quite physically distinct [29]. This is manifest in a lack of agreement within the databases of Indian government departments regarding the number of villages in India, varying from 600,000 to one million [30]. Forest reserve hamlets and un-surveyed settlements are typically not included in Census village counts, thus missing out on government 


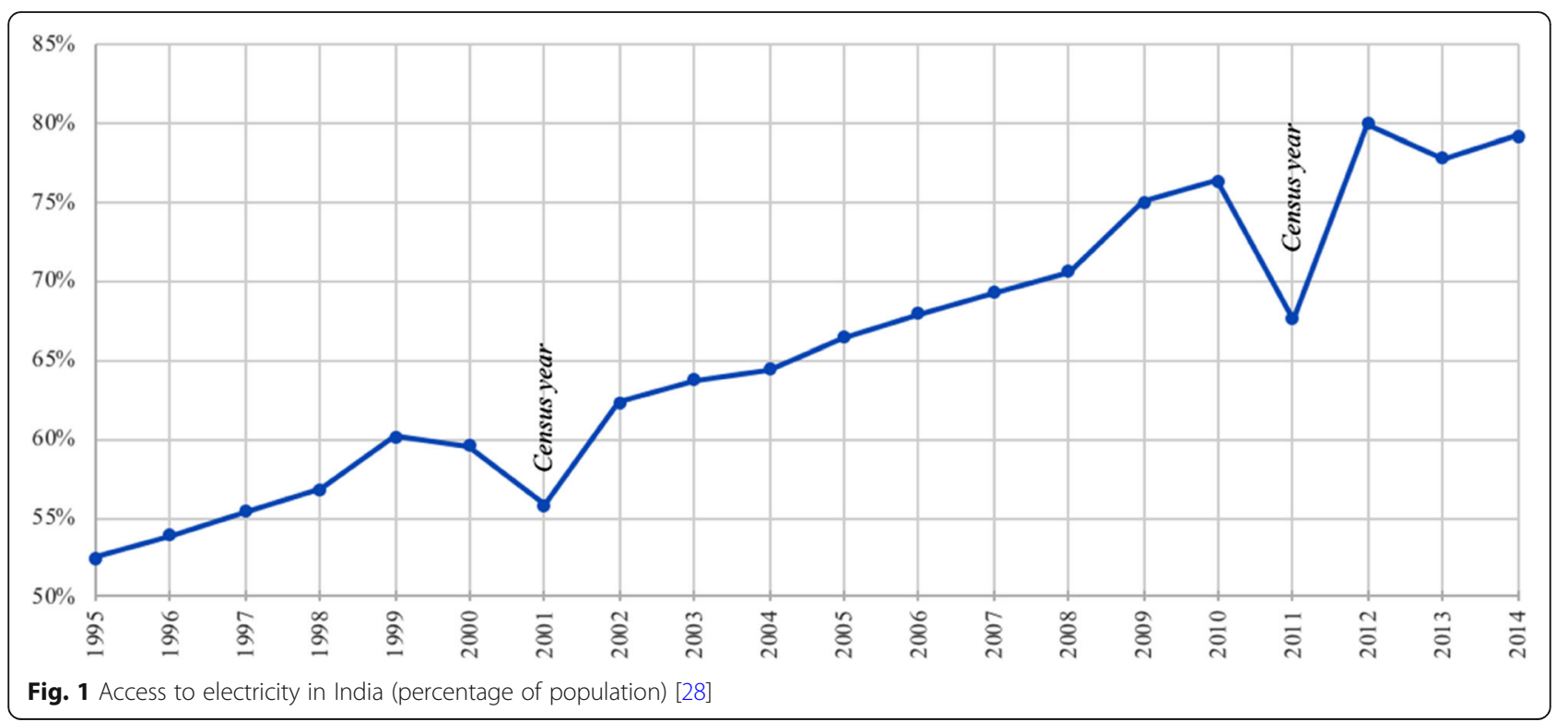

electrification programs and other services entirely [31]. For example, the principal author has visited the small tribal hamlet (pada) of Vanvasi in Maharashtra, consisting of 42 households. This forest reserve settlement was not separately recorded on the Census and was observed to have a general absence of government services, including electricity supply. This is despite the fact that electricity transmission lines pass directly overhead the hamlet's agricultural fields-indicating some awareness of the existence of this hamlet by government service providers but no action to intervene.

Reliability and quality of electricity supply, tracked by Prayas (Energy Group)'s Electricity Supply Monitoring Initiative (ESMI) at 202 locations across rural and urban India, continue to be significant issues, with metrics in fact showing a deterioration from October 2017 to October 2018. In $2018,56 \%$ of locations experienced outages for more than a 15-h duration during October (compared with 52\% in 2017), 38\% of locations experienced more than 30 interruptions (each greater than $15 \mathrm{~min}$ ) during October (compared with $27 \%$ in 2017), and $33 \%$ of locations experienced average daily outages of more than $30 \mathrm{~min}$ during evening hours in October (compared with $22 \%$ in 2017) [32]. Further, rural areas face disproportionate reliability issues due to their high transmission losses and dominance of agricultural pump sets, which incur financial losses [33]. In October 2018, just $11 \%$ of ESMI's rural locations received an entire $6 \mathrm{~h}$ of evening electricity supply, compared with $77 \%$ in mega cities and $43 \%$ in other cities [32].

Even if homes are connected, if the supply remains unreliable, households would still remain mired in energy poverty. Whilst India has declared a national power surplus [34], 'load shedding', where distribution companies plan supply outages to balance supply and demand [35], continues to occur in many parts of the country. This is fundamentally a result of mismatches in supply and demand of power across different times of the day (e.g. India's residential demand peaks in the evening). Acknowledging the high residential load in some parts of India [36], electricity reliability is driven by the ability of different types of consumers (industrial, commercial, or residential) to produce adequate revenue to pay back investment. Residential consumers, for example, typically provide lower revenues, which require cross-subsidisation. Thus, load shedding may be preferentially undertaken in areas with high collection losses, where not supplying power is more economical than supplying power and not recovering costs.

Investors in generation assets must also contend with known issues within their direct customer base, the state distribution companies [37]. Distribution companies generally exhibit poor operating and financial efficiencies, with high levels of theft from their residential customers and complex subsidisation arrangements. This notionally insecure revenue stream may restrict investment in highly capital-intensive centralised generation assets [37]. Nevertheless, distribution and historical equity issues remain critical to energy access in India. For example, in Maharashtra, the historical focus on agricultural development has ensured an extensive grid network which was initially installed to power water pumps [38], ensuring a dense transmission network covering much of the state.

Poor electricity reliability has a number of cumulative implications due to negative feedback loops. For consumers, load shedding directly reduces the reliability of electricity and reduces their satisfaction and corresponding willingness to pay for electricity, driving further collection losses [39]. In addition, high-load shedding may lead to electrified villages becoming de-electrified due 
to inoperative distribution infrastructure [5], with such villages eventually having to re-enter the DDUGJY program.

Affordability is a key parameter that heavily influences the relationship between connectivity and use for both grid and off-grid systems [33]. Energy supplying 'basic human needs' can be satisfied by incumbent environmental resources, including biomass (such as wood and animal dung) for cooking; sunshine for drying; and manual labour [40]. These resources are 'free' in a monetary sense, although their use has health impacts (from hazardous smoke), social impacts (especially among women and children) and significant impacts on the ecosystems from which biomass is sourced [41]. The enabling uses of energy may become more expansive through increased energy supply levels, such as from fuel-based lighting and batteries, which may also charge mobile phones. There are potential market opportunities here for grid and off-grid energy systems as substitutions for incumbent technologies like kerosene lamps [42]. The effects on household energy budgets are extremely important in the context of uptake and acceptance of the new technology [43]. Whilst upfront costs may be higher, there is often a net decrease in household energy-related expenditure over the longer term $[44,45]$. In Odisha, BPL grid consumers pay a fixed monthly charge of ₹80 (approximately US\$1) [46] and their initial grid connection is free under the Saubhagya scheme [19]. Nevertheless, in CEEW's recent study [26], unelectrified households reported that perceived upfront costs are a deterrent to getting a connection, suggesting problems in the implementation of the program. Off-grid suppliers often partner with micro-finance providers [47] and may offer pay-as-you-go (PAYG) payment schemes [48], to overcome these barriers.

Thus, the mismatch between the $100 \%$ village electrification milestone and the 305 million people forming the unconnected 'last mile' of electricity access may be largely attributed to Census village definitions, the poor reliability of the grid and affordability barriers. Clearly, there is a need to go beyond the current government understandings of electrification and demographics and the performance indicators of village and household connectivity [39]. The shortcomings in the quality of electricity supply, and, ultimately consumer satisfaction and associated livelihood improvements, create opportunities for alternative electricity supply systems.

\section{Off-grid electrification}

\section{Government off-grid delivery}

The MNRE issued a draft National Policy on renewable energy based mini- and micro-grids in 2016 [49], which encouraged the development of state-level policies and regulations. This policy included a target of 10,000 off-grid projects by 2022, with a total installed capacity of $500 \mathrm{MW}$. As identified by $\mathrm{Ma}$ and Urpelainen [21], this is very small compared with India's total installed generation capacity of over $346 \mathrm{GW}$ (as at November 2018 [50]). Further, as one $50 \mathrm{~kW}$ off-grid system typically provides basic levels of lighting, mobile phone charging and television for 500 households, the National Policy's off-grid target would provide electricity to five million households [21] or 24 million people (based on the average household occupancy in India [51]). The MNRE reported that in 2017, over 1.2 million households were using off-grid solar energy for lighting, with a similar number of households using biogas plants for cooking [52]. The government also has various renewable energy targets for 2022, including $100 \mathrm{GW}$ from solar projects (with $40 \mathrm{GW}$ from decentralised rooftop solar projects), $60 \mathrm{GW}$ from wind, $10 \mathrm{GW}$ from bio-power and $5 \mathrm{GW}$ from small hydro-power [52].

Within the DDUGJY, of the 18,452 villages on the 2015 electrification list, 2638 villages were identified as being grid-inaccessible and have had off-grid systems provided by the Indian government, as at December 2017. Despite the push for the grid expansion in India, at a certain distance away from existing grid infrastructure, off-grid systems are inevitably cheaper $[33,53]$, although the viability dynamics continue to change with expansion. As grid connections are the dominant political paradigm, there is no evidence of economic optimisation of grid/off-grid composition by the government, thereby forgoing any cost savings that could be realised by off-grid installations.

Renewable energy is generally favoured for off-grid systems in remote regions, with over half of the systems in India using solar (photovoltaic) technology [37]. Off-grid systems can range from DRE systems, such as micro-grids or mini-grids, to Solar Home Systems (SHS) for individual households. Under commitments related to the Saubhagya implementation, households in off-grid villages will generally receive SHS with battery backup, light -emitting diode (LED) lamps, a direct-current fan and power plug, along with repair and maintenance for five years [19]. Despite the commitment to off-grid systems, the true extent of off-grid systems, installed by both the government and the private sector, is somewhat opaque. Thus, the following section discusses the roles and opportunities for the private sector along with a situational analysis of off-grid operations in Maharashtra and Odisha.

\section{Key considerations for the private sector}

Beyond government electrification delivery, private sector off-grid solutions from firms and NGOs may well provide the only response to the energy access needs of 'Base of the Pyramid' (BoP) consumers, particularly in 'forgotten' tribal communities bereft of government services. Further, there is evidence that off-grid firms may be able to identify and integrate into informal economies where formal government services are unable to be established [54]. For example, in Vanvasi pada and other 
tribal hamlets in Maharashtra not recorded on the Census, solar micro-grid systems have been installed by the private sector operator Gram Oorja, in partnership with the NGO Pragati Pratishthan [55].

Private sector off-grid systems may also have a role to play in providing back-up 'Remedial Secondary Infrastructure' [56] to unreliable grid services in currently electrified villages, although this is not without risk given the government's commitments to reliability improvements [57]. This market niche may be persistent, even when government services improve, due to a build-up of mistrust surrounding the unreliability of government infrastructure over time $[6,53,58]$. Further, private sector off-grid systems can become socially-embedded in communities, playing an important role in producing innovative, community-led solutions [7, 22]. The sector is often at the forefront of trialling new energy technologies with the potential to leapfrog traditional electrification paradigms [59].

Given the issues of connectivity and reliability, the opportunities and threats for private sector off-grid projects are presented in Table 1. Whilst off-grid systems may play an important role in the electrification of India in responding to niche opportunities, the table shows the considerable threats for the private sector. Industry body CLEAN noted 'the private sector faces significant risks, primarily due to government's lack of a coordinated and integrated policy approach to optimise solutions to India's energy poverty' (pers. comm., 24 March 2017).

\section{Situation analysis-Maharashtra and Odisha}

Analyses of operations identified in Prayas (Energy Group)'s DRE map [25] and data from selected off-grid operators, MEDA and OREDA, provide some insight on off-grid penetration in Maharashtra and Odisha. In Maharashtra, MEDA's Remote Village Electrification Scheme has delivered SHS to 343 villages and 704 hamlets since 2005 (pers. comm., MEDA, 23 March 2017). Under the scheme, MEDA's objective has been to provide systems to all unelectrified remote Census villages and hamlets, and provides the systems (and ongoing maintenance) free of charge to households. The list of villages and hamlets to be targeted by MEDA is determined by Maharashtra's state distribution company, who certifies that such locations will not be electrified by the central grid within 5 years. MEDA prefers SHS as a cost-effective way to meet electrification targets (pers. comm., MEDA, 23 March 2017). Turning to the private sector's implementation of off-grid systems in Maharashtra, Prayas (Energy Group)'s map does not reveal any DRE systems in the state, but five systems were identified from Gram Oorja [55]. Three of these locations were able to be located on the Census database, with the exception being the two tribal hamlets of Darewadi and Vanvasi in Maharashtra's tribal belt. All were locatable on Google Maps, mostly adjacent to villages or wildlife sanctuary, with the exception of Vanvasi.

In Odisha, the Remote Village Electrification Program administered by OREDA has electrified 1621 villages since 2006, mostly via SHS, with some DRE mini-grids (pers. comm., OREDA, 28 March 2017). Whilst the systems are installed at no cost to the consumer, tariffs (₹30 (US\$0.43)/month) are collected from households (via a village account) that contribute to an ongoing maintenance scheme. Remote, hilly locations, often surrounded by conservation zones, constitute the typical sites where the program is implemented. Site selection is undertaken jointly by OREDA and the distribution companies. Notably, OREDA is implementing a livelihood program to complement its off-grid systems in selected villages, aiming to create support ecosystems to promote income-generating energy uses in agriculture and small businesses. Importantly, villages and hamlets where MEDA and OREDA have implemented off-grid systems are considered fully electrified by the DDUGJY and all levels of government, even though the electrification technology is generally limited to SHS and solar street lighting. Overall, OREDA has implemented more off-grid systems than MEDA, due in part to the greater electrification challenge in Odisha and also due to the large conservation and insurgent-controlled areas in the state [60].

Prayas (Energy Group)'s map showed 33 DRE operations in Odisha, with the majority operated by OREDA and the Odisha forestry department. The map revealed

Table 1 Opportunities and threats for private sector off-grid electricity distribution

\begin{tabular}{|c|c|c|}
\hline Electrification status & Opportunities & Threats \\
\hline $\begin{array}{l}\text { Grid connected households } \\
\text { and localities }\end{array}$ & $\begin{array}{l}\text { - High-reliability solutions embedded } \\
\text { within communities }\end{array}$ & $\begin{array}{l}\text { - Price competition from very low tariffs for } \\
\text { grid electricity, particularly for BPL consumers } \\
\text { - Increased household grid connections and } \\
\text { reliability improvements over time }\end{array}$ \\
\hline $\begin{array}{l}\text { Off-grid remote } \\
\text { Census villages }\end{array}$ & $\begin{array}{l}\text { - Interim, high-reliability solutions embedded } \\
\text { within communities, with 'first-mover' advantage } \\
\text { - Supply to Saubhagya off-grid scheme and } \\
\text { further integration with government programs }\end{array}$ & $\begin{array}{l}\text { - Lack of transparency on Saubhagya government } \\
\text { electrification roll-out } \\
\text { - Price competition from (free) Saubhagya off-grid } \\
\text { systems }\end{array}$ \\
\hline Non-Census hamlets & $\begin{array}{l}\text { - Fully community-embedded, high-reliability } \\
\text { solutions, with 'first-mover' advantage }\end{array}$ & $\begin{array}{l}\text { - Low income diversity in BPL hamlets - difficulties } \\
\text { in sustaining business models }\end{array}$ \\
\hline
\end{tabular}


13 of the systems were operated by local NGOs. In analysing site locations on Google Maps, Odisha's DRE locations were either within or adjacent to forest reserves or wildlife sanctuaries. Non-Census hamlets made up only two locations in the off-grid list examined. Thus it seems that the private sector has located off-grid systems regardless of the potential for government-provided electricity (in Census villages). Interestingly, there are no sites where government and private sector off-grid systems were co-located. This is despite the fact that in interviews, MNRE, MEDA and OREDA all commented that they do not have a comprehensive understanding of the locations and types of off-grid systems provided by the private sector. This was further validated by a study that determined that the extent of the (present or planned) grid did not inhibit the market for off-grid solar technologies [7]. The unreliability and poor quality of grid electricity may be a key factor, creating market opportunities for off-grid solutions, even when the grid is present.

\section{Key findings}

The review of grid and off-grid electrification provided by the government found extensive programs to provide villages and households with electricity access. The unconnected 305 million people forming the 'last mile' of access can be attributed to coarse metrics on electrification and demographics, poor grid reliability and affordability issues. In this light, a market niche (although ill-defined) exists for private sector off-grid solutions in alternative electricity supply systems. The situation analysis of Maharashtra and Odisha showed that this opportunity for private sector off-grid systems was being met by limited engagement, operating on the periphery of government grid and off-grid paradigms. Private sector involvement was seen to be limited and somewhat incidental in nature, operating below the official government system and in some cases responding to localities not recorded on the Census. This is generally contrary to literature and conventional thinking which typically highlights the large potential market for off-grid power [5, 9].

\section{Conclusions}

This paper has shown that the interaction between India's electrification paradigms and private sector opportunities largely occurs at the periphery of the grid system, but that opportunities do exist. Investigation of the country's current paradigms showed the dominance of the government's roll-out of the central electricity grid. However, the strong government push for village and household grid connections is somewhat disconnected from household electricity use, and it is likely that some 'forgotten' non-Census hamlets will remain unconnected. In addition, the grid's poor quality and reliability, especially for electricity consumers in more remote areas, remains a major issue. Although off-grid systems are clearly in the government's mix of solutions to address India's energy poverty, the government has so far under-emphasised the role that off-grid technologies play due to political promises and policy settings, both firmly focussed on grid connections.

In India's quest for universal energy access, accounting for every habitation and every customer in its complex socio-cultural setting is difficult. This is exacerbated when universal energy access is being addressed via a centralised paradigm based on coarse definitions. This mismatch in granularity could be overcome through more localised solutions that can access the obstinate 305 million 'last mile' consumers. Off-grid systems provided by the private sector may provide a more suitable, nuanced vehicle for this. It appears that the opportunities for the private sector predominantly relate to the unreliability of the grid and its reach to individual households and 'forgotten' non-Census habitations. However, the analysis undertaken in this paper has shown a subdued response in the delivery of off-grid systems in Maharashtra and Odisha. Such operations are somewhat incidental in nature, operating with little connectivity with, or regard to, government systems. The centrally planned grid contributes significantly to the business risks of the private sector in BoP off-grid markets, even though there is an apparent need for localised, socially-embedded approaches to reach 'last mile' consumers.

The following policy recommendations may allow more market certainty and incentives:

1) Increased transparency in the functioning of the grid system is an important element to understanding gaps and shortcomings in India's electrification efforts. This would involve shifting the Indian government's metrics of electrification, which currently focus on infrastructure connections at village and household levels, towards a multidimensional, multi-tiered approach to energy access [25] that includes the quality of electricity provided (expressed in term of consistency of voltage and duration of supply per day). Replicating Census surveys on a yearly basis, examining electricity used for lighting within households, would give a truer reflection on the utility of electricity by consumers, which is the intrinsic goal of energy provision. Transparent government plans for future village and hamlet electricity connections would give greater certainty on timeframes for off-grid investment by the private sector.

2) Understanding the extent of 'forgotten' hamlets in India: at the moment, knowledge about such hamlets seems to be largely vested at a sub-regional level via local NGOs (such as Pragati Pratishthan which is focussed on the tribal belt of Maharashtra). 
Strengthening of meso-level intermediary institutions such as Prayas (Energy Group) and NGO collectives would assist in understanding the needs of such communities, communication between communities on energy systems and the governance gap between central government electrification programs and implementation via state distribution companies.

3) Finally, the Indian government could formally recognise the role of the private sector in India's electrification objectives. This could come in the form of the government transferring responsibilities for household electricity access to local-level businesses and community organisations (in partnership with distribution companies), improving social embeddedness and potentially overcoming affordability barriers. Off-grid systems provided by the local firms and community organisations may potentially reach 'forgotten' communities and households. Some international examples show how the government can provide funding/subsidies to support local providers. In China, off-grid systems developed and managed by local communities and funded by the government [37] are an important part of electrification programs, while in Bangladesh, the widespread deployment of SHS is undertaken through public-private partnerships [61].

It is clear that private sector off-grid systems, currently playing a remedial, secondary role, could be mainstreamed within India's electrification planning. This would optimise the contributions of the private sector towards electrifying the BoP. The business certainty that this would provide would also allow the private sector to develop innovations that could provide more integrated, cost-effective and deployable energy services, reaching the 305 million 'last mile' consumers spread across challenging geographic and social contexts.

\section{Endnotes}

${ }^{1}$ Large parts of eastern, central and southern India, including Odisha, experience considerable 'Naxalite-Maoist' left-wing insurgency in areas of high poverty and social stratification [16]. This ongoing conflict affects the delivery and maintenance of government services.

\footnotetext{
Abbreviations

₹: Indian rupee; BoP: Base of the Pyramid; BPL: Below Poverty Line; CEEW: Council on Clean Energy, Environment and Water; CLEAN: Clean Energy Action Network; DDUGJY: Deen Dayal Upadhyaya Gram Jyoti Yojana; DRE: Distributed Renewable Energy; ESMI: Electricity Supply Monitoring Initiative; IIT: Indian Institute of Technology; LED: Light-emitting diode; MEDA: Maharashtra Energy Development Agency; MNRE: Ministry of New and Renewable Energy; NGO: Non-Government Organisation; OERC: Odisha Electricity Regulatory Commission; OREDA: Odisha Renewable Energy Development Agency; PAYG: Pay-as-you-go; RGGVY: Rajiv Gandhi Grameen Vidyutikaran Yojana; SECC: Socio-Economic and Caste Census; SHS: Solar
}

Home Systems; TERI: The Energy and Resources Institute; US\$: United States dollar; XIMB: Xavier Institute of Management Bhubaneswar

\section{Acknowledgements}

Not applicable

\section{Funding}

This research was completed as part of a higher degree research program at The University of Queensland (UQ), and funded by UQ.

\section{Availability of data and materials}

The datasets used and/or analysed during the current study are available from the corresponding author on reasonable request.

\section{Authors' contributions}

$\mathrm{AH}$ conceived the research work and the methodological design and undertook all research data collection and analysis with supervisory input from PL, SS, CG and SS. All authors read and approved the final manuscript.

\section{Ethics approval and consent to participate}

This research involved discussion with key stakeholders as part of a validation of findings. This study was approved by the School of Chemical Engineering Ethics Committee (Reference CE17C01) in accordance with the ethical review guidelines and processes of The University of Queensland. These guidelines are endorsed by the University's principal human ethics committee, the Human Experimentation Ethical Review Committee and complies with the National Statement on Ethical Conduct in Human Research (Australia).

\section{Consent for publication}

Not applicable

\section{Competing interests}

The authors declare that they have no competing interests.

\section{Publisher's Note}

Springer Nature remains neutral with regard to jurisdictional claims in published maps and institutional affiliations.

\section{Author details}

${ }^{1}$ Energy \& Poverty Research Group, School of Chemical Engineering, The University of Queensland, Brisbane, Australia. ${ }^{2}$ Dow Centre for Sustainable Engineering Innovation, School of Chemical Engineering, The University of Queensland, Brisbane, Australia. ${ }^{3}$ Department of Marketing, Monash Business School, Monash University, Melbourne, Australia.

Received: 4 October 2018 Accepted: 26 April 2019

Published online: 22 May 2019

\section{References}

1. Modi N [@narendramodi] (2018) 28th April 2018 will be remembered as a historic day in the development journey of India. Yesterday, we fulfilled a commitment due to which the lives of several Indians will be transformed forever! I am delighted that every single village of India now has access to electricity. https://twitter.com/narendramodi/status/ 990455176581517312?lang=en

2. Aayog NITI (2017) Draft National Energy Policy. National Institution for Transforming India, Government of India, New Delhi http://niti.gov.in/ writereaddata/files/new_initiatives/NEP-ID_27.06.2017.pdf. Accessed 5 Dec 2017

3. IEA (2017) World Energy Outlook 2017. International Energy Agency, Paris

4. Malakar Y (2018) Evaluating the role of rural electrification in expanding people's capabilities in India. Energy Policy 114:492-498

5. Palit D, Bandyopadhyay KR (2016) Rural electricity access in South Asia: is grid extension the remedy? A critical review. Renew Sust Energ Rev 60: 1505-1515

6. Urpelainen J (2014) Grid and off-grid electrification: an integrated model with applications to India. Energy Sustain Dev 19:66-71

7. Singh K (2016) Business innovation and diffusion of off-grid solar technologies in India. Energy Sustain Dev 30:1-13

8. Singh S, Saurabh K, Bajpai S (2016) History of electric power in India (18902015). J Electric Power Syst Eng 2(1):38-45 
9. The Climate Group (2015) The business case for off-grid energy in India. The Climate Group, New Delhi https://www.theclimategroup.org/sites/default/ files/archive/files/The-business-case-for-offgrid-energy-in-India.pdf

10. Knuckles J (2016) Business models for mini-grid electricity in base of the pyramid markets. Energy Sustain Dev 31:67-82

11. Government of India (2003) Electricity Act. www.cercind.gov.in. Accessed 16 Nov 2016

12. Government of India (2006) Rural electrification policy. www.ielrc.org/ content/e0639.pdf. Accessed 16 Nov 2016

13. GARV (2018) Dashboard. garv.gov.in/dashboard\#prev. Accessed 13 Apr 2017.

14. DDUGJY (2016) About us. http://www.ddugjy.gov.in/ Accessed 20 Sep 2016

15. Ministry of Home Affairs (2011) 2011 Census of India. Office of the Registrar General \& Census Commissioner, Government of India. http://www. censusindia.gov.in/2011census/censusdata2k11.aspx. Accessed 15 Nov 2017

16. Öberg M, Strøm K (2008) Resources, governance and civil conflict. Routledge, London

17. Pearce D, Webb M (1987) Rural electrification in developing countries: a reappraisal. Energy Policy 15(4):329-338

18. Bansal S (2016) On paper, electrified villages - in reality, darkness. The Hindu. http://www.thehindu.com/opinion/op-ed/on-paper-electrifiedvillages-in-reality-darkness/article8397038.ece. Accessed 8 Nov 2016

19. Government of India (2017) Frequently asked questions on Saubhagya Pradhanmantri Sahaj Bijli Har Ghar Yojana. http://saubhagya.gov.in/faq. Accessed 7 Jan 2019.

20. Palit D, Bandyopadhyay KR (2017) Rural electricity access in India in retrospect: a critical rumination. Energy Policy 109:109-120

21. Ma S, Urpelainen J (2018) Distributed power generation in national rural electrification plans: an international and comparative evaluation. Energy Res Soc Sci 44:1-5

22. Heynen AP, Lant PA, Sridharan S, Smart S, Greig C, (2019) The role of private sector off-grid actors in addressing India's energy poverty: An analysis of selected exemplar firms delivering household energy. Energy and Buildings 191:95-103

23. Government of India (2018) Saubhagya data. http://saubhagya.gov.in. Accessed 13 Apr 2018

24. NITI Aayog (2016) State Statistics. National Institution for Transforming India, Government of India, New Delhi http://niti.gov.in/state-statistics. Accessed 16 Oct 2016

25. Prayas (Energy Group) (2014) A map of distributed renewable energy (DRE) micro-grids in India. www.prayaspune.org/peg/publications/item/275-microgrid-map.html. Accessed 6 Oct 2016

26. Jain A, Tripathi T, Mani S, Patnaik S, Shahidi T, Ganesan K (2018) Access to clean cooking energy and electricity - survey of states 2018. In: Council on Energy, Environment and Water (CEEW) report, New Delhi. https:/www. ceew.in/sites/default/files/CEEW-Access-to-Clean-Cooking-Energy-andElectricity-11Jan19_0.pdf. Accessed 18 Jan 2019.

27. Jaisinghani $N$ (2017) Global electrification progress: when your error term is hundreds of millions of people. Available via Linkedln. https://www.linkedin. $\mathrm{com} /$ pulse/global-electrification-progress-rosy-data-suggests-nikhiljaisinghani. Accessed 6 Dec 2017

28. World Bank (2018) Access to electricity (\% of population) India. https://data. worldbank.org/indicator/EG.ELC.ACCS.ZS?end=2014\&locations=IN. Accessed 6 Dec 2017

29. The Indian Express (2016) Reaching the last village. http://indianexpress. com/article/opinion/columns/india-urbanization-2011-census-report2820935/. Accessed 16 Nov 2016

30. Verma R (2017) India unclear how many villages it has, and why that matters. India Spend. http://www.indiaspend.com/cover-story/india-unclearhow-many-villages-it-has-and-why-that-matters-56076. Accessed 11 Oct 2017

31. Ministry of Tribal Affairs (2014) Report of the high level committee on socioeconomic, health and educational status of tribal communities of India. Government of India, New Delhi http://www.indiaenvironmentportal.org.in/ files/file/Tribal\%20Committee\%20Report,\%20May-June\%202014.pdf. Accessed 28 Oct 2017

32. Prayas (Energy Group) (2018) Electricity Supply Monitoring Initiative (EMSI) analysis reports - October 2017 and 2018. www.watchyourpower.org/ uploaded_reports.php. Accessed 11 Dec 2018

33. Harish SM, Morgan GM, Subrahmanian E (2014) When does unreliable grid supply become unacceptable policy? Costs of power supply and outages in rural India. Energy Policy 68:158-169
34. Central Electricity Authority (2017) Load Generation Balance Report 201718. Ministry of Power, Government of India, New Delhi http://www.cea.nic. in/reports/annual/lgbr/lgbr-2017.pdf. Accessed 12 Dec 2017

35. Kumar S, Singh A (2017) Shedding light on Saubhagya: on electrification scheme. The Hindu. http://www.thehindu.com/opinion/op-ed/sheddinglight-on-saubhagya/article19913598.ece. Accessed 5 Dec 2017

36. Molyneaux L, Wagner L, Foster J (2016) Rural electrification in India: Galilee Basin coal versus decentralised renewable energy micro grids. Renew Energy 89:422-436

37. Mukherjee M (2014) Private participation in the Indian power sector: lessons from two decades of experience. World Bank Publications, New York

38. Kale SS (2014) Electrifying India: regional political economies of development. Stanford University Press, Stanford

39. Aklin M, Cheng CY, Urpelainen J, Ganesan K, Jain A (2016) Factors affecting household satisfaction with electricity supply in rural India. Nat Energy 1:16170

40. Yadama GN (2013) Fires, fuel, and the fate of 3 billion: the state of the energy impoverished. Oxford University Press, Oxford

41. Cabraal RA, Barnes DF, Agarwal SG (2005) Productive uses of energy for rural development. Annu Rev Environ Resour 30:117-144

42. Roy J, Jana S (1998) Solar lanterns for rural households. Energy 23:67-68

43. Scott I (2017) A business model for success: enterprises serving the base of the pyramid with off-grid solar lighting. Renew Sust Energ Rev 70:50-55

44. Grimm M, Munyehirwe A, Peters J, Sievert M (2016) A first step up the energy ladder? Low cost solar kits and household's welfare in rural Rwanda. World Bank Policy Research Working Paper No. 7859. https:// openknowledge.worldbank.org/handle/10986/25304. Accessed 5 Dec 2017

45. Kudo Y, Shonchoy AS, Takahashi K (2017) Can solar lanterns improve youth academic performance? Experimental evidence from Bangladesh. The World Bank policy research working paper 7954. https://doi.org/10.1596/18139450-7954. Accessed 5 Dec 2017

46. Odisha Electricity Regulatory Commission (2016) Retail supply tariff. www. southcoodisha.com/tend/TARIFF_NOTIFICATION.pdf. Accessed 5 Dec 2017

47. Malhotra A, Schmidt TS, Haelg L, Waissbein O (2017) Scaling up finance for off-grid renewable energy: the role of aggregation and spatial diversification in derisking investments in mini-grids for rural electrification in India. Energy Policy 108:657-672

48. Yadav P, Heynen AP, Palit D (2019) Pay-as-you-go financing: a model for viable and widespread deployment of solar home systems in rural India. Energy Sustain Dev 48:139-153

49. Ministry of New and Renewable Energy (2016) Draft National Policy on RE based mini/micro grids. Government of India, New Delhi https://mnre.gov. in/file-manager/UserFiles/draft-national-Mini_Micro-Grid-Policy.pdf. Accessed 18 Nov 2018

50. Central Electricity Authority (2018) Installed capacity - November 2018. Government of India, New Delhi http://www.cea.nic.in/ monthlyinstalledcapacity.html Accessed 1 Dec 2018

51. United Nations (2017) Household Size and Composition Around the World 2017. http://www.un.org/en/development/desa/population/publications/ pdf/ageing/household_size_and_composition_around_the_world_2017_ data_booklet.pdf. Accessed 1 Dec 2018

52. Ministry of New and Renewable Energy (2017) Annual Report 2016-2017. Government of India, New Delhi https://mnre.gov.in/file-manager/annualreport/2016-2017/EN/pdf/1.pdf. Accessed 16 Feb 2019.

53. Nouni MR, Mullick SC, Kandpal TC (2008) Providing electricity access to remote areas in India: an approach towards identifying potential areas for decentralized electricity supply. Renew Sust Energ Rev 12(5):11871220

54. London T, Hart SL (2004) Reinventing strategies for emerging markets: beyond the transnational model. J Int Bus Stud 35(5):350-370

55. Gram Oorja (2017) Our projects. http://gramoorja-testsite.botbakery.io/ portfolio-items/solar-micro-grids/. Accessed 18 Nov 2017.

56. Reiner MB, Ramaswami A (2016) What is remedial secondary infrastructure? Implications for infrastructure design, policy for sustainability, and resilience. J Infrastruct Syst 22(2):02516001

57. Waray S (2017) Bringing 24x7 power to all by 2022. The Hindu Business Line http://www.thehindubusinessline.com/opinion/bringing-24x7-power-to-allby2022/article9852008.ece. Accessed 11 Oct 2017

58. Blenkinsopp T, Coles SR, Kirwan K (2013) Renewable energy for rural communities in Maharashtra, India. Energy Policy 60:192-199

59. Levin T, Thomas VM (2016) Can developing countries leapfrog the centralized electrification paradigm? Energy Sustain Dev 31:97-107 
60. Financial Express (2016) Naxal hit, inaccessible villages to get off-grid power. www.financialexpress.com/india-news/naxal-hit-inaccessible-villages-to-getoff-grid-power/346273/ Accessed 16 Nov 2017

61. Yunus M, Moingeon B, Lehmann-Ortega L (2010) Building social business models: lessons from the Grameen experience. Long Range Plan 43(2-3): 308-325

Ready to submit your research? Choose BMC and benefit from:

- fast, convenient online submission

- thorough peer review by experienced researchers in your field

- rapid publication on acceptance

- support for research data, including large and complex data types

- gold Open Access which fosters wider collaboration and increased citations

- maximum visibility for your research: over $100 \mathrm{M}$ website views per year

At BMC, research is always in progress.

Learn more biomedcentral.com/submissions 